\title{
MANAJEMEN KEPALA MADRASAH DALAM MENINGKATKAN KOMPETENSI PROFESIONAL GURU PENDIDIKAN AGAMA ISLAM
}

\author{
Husni Tamrin ${ }^{1}$, Nuzuar ${ }^{2}$, Syahrial Dedi $^{2}$ \\ Program Pascasarjana IAIN Curup ${ }^{1,2,3}$ \\ tamrin.tamrin1989@gmail.com ${ }^{1}$
}

\begin{abstract}
ABSTRAK
Tujuan penelitian ini untuk mengetahui manajemen kepala madrasah dalam meningkatkan kompetensi professional guru pendidikan agama Islam. Dalam penelitian ini, penulis menggunakan jenis penelitian kualitatif dengan pendekatan deskriptif yaitu penelitian yang mendeskripsikan atau menggambarkan keadaan atau status fenomena. Hasil penelitian, beberapa hal yang perlu dilakukan kepala madrasah antara lain: 1) Mengetahui keadaan/kondisi guru dalam latar belakang kehidupan lingkungan, social dan ekonominya, 2) merangsang semangat kerja guru dengan berbagai cara, 3) menguasahankan tersedianya fasilitas yang diperlukan untuk mengembangkan kemampuan guru, 4) meningkatkan partisipasi guru di lingkungan sekolah, 5) membina rasa kekeluargaan dilingkungan sekolah, 6) mempererat hubungan sekolah dengan masyarakat, komite dan wali siswa. Simpulan, manajemen kepala madrasah dalam meningkatkan kompetensi profesional guru pendidikan agama Islam (PAI) adalah: 1) mengikutsertakan guru dalam kegiatan diklat, 2) mengedepankan kedisiplinan, 3) memotivasi guru, 4) supervisi. Simpulan, Penerapan dari menajemen kepala madrasah di MA AlManshuriyah sungai baung sudah terlaksana, kompetensi professional guru PAI di MA Al-Manshuriyah sudah sangat bagus
\end{abstract}

Kata Kunci: Manajemen Kepala Sekolah, Kompetensi Guru PAI

\begin{abstract}
The purpose of this study was to determine the management of madrasa principals in improving the professional competence of Islamic religious education teachers. In this study, the authors used a type of qualitative research with a descriptive approach that is research that describes or illustrates the state or status of phenomena. The results of the study, several things that need to be done by the madrasa head include: 1) Knowing the condition / condition of the teacher in the background of environmental, social and economic life, 2) stimulating the teacher's work spirit in various ways, 3) maintaining the availability of facilities needed to develop the ability teacher, 4) increasing teacher participation in the school environment, 5) fostering a sense of family within the school environment, 6) strengthening the relationship of the school with the community, committee and student guardians. Conclusions, the management of madrasas in improving the professional competence of Islamic religious education teachers (PAI) are: 1) involving teachers in training activities, 2) promoting discipline, 3) motivating teachers, 4) supervision. Conclusion, The application of the management of the madrasa head at the MA Al-Manshuriyah Sungai Baung has already been
\end{abstract}


implemented, the professional competence of PAI teachers at the Al-Manshuriyah MA has been very good

\section{Keywords: Principal Management, PAI Teacher Competence}

\section{PENDAHULUAN}

Keberhasilan suatu lembaga pendidikan sangat tergantung pada kepemimpinan kepala madrasah, keberhasilan sekolah adalah keberhasilan kepala madrasah (Wahjosumidjo, 2005). Bagaimanapun, kepala madrasah merupakan unsur vital bagi efektifitas lembaga pendidikan. Tidak akan kita jumpai sekolah yang baik dengan kepala madrasah yang buruk atau sebaliknya sekolah yang buruk dengan kepala madrasah yang baik. Kepala madrasah yang baik akan bersikap dinamis untuk menyiapkan berbagai macam program pendidikan. Bahkan, tinggi rendahnya mutu suatu sekolah akan dibedakan oleh kepemimpinan kepala madrasah (Sulistyorini, 2009).

Kepemimpinan berkaitan dengan masalah kepala madrasah dalam meningkatkan kesempatan untuk mengadakan pertemuan secara efektif dengan para guru dalam situasi yang kondusif. Perilaku kepala madrasah harus dapat mendorong kinerja para guru dengan menunjukan rasa bersahabat, dekat dan penuh pertimbangan terhadap para guru, baik sebagai individu maupun sebagi kelompok. Perilaku pemimpin yang positif dapat mendorong kelompok dalam mengarahkan dan memotifasi individu untuk bekerja sama dalam kelompok dalam rangka mewujudkan tujuan lembaga pendidikan (Sulistyorini, 2009).

Bagi seorang pengamat pendidikan atau seorang intelektual, input dan output bukanlah suatu penentu bagi sebuah lembaga pendidikan dikatakan baik atau suksesnya seorang kepala sekolah dalam memimpin sebuah lembaga, bisa saja suatu lembaga dalam melakukan input nya asal memasukan siswa yang penting bisa memperoleh siswa yang banya tanpa mengikuti prosedur yang ada. Dalam output juga banyak yang kita dengar atau kita lihat realitas yang ada, semua siswa yang ada harus dituntut lulus semua $100 \%$ pas ketika UN, sehingga pihak sekolah harus meluluskan demi menjaga nama baik sekolah. Input dan output tidaklah lengkap tanpa adanya proses yang baik. Yang punya peran mengelola proses ini adalah seorang kepala sekolah, disini kepala sekolah mempunyai peran penting untuk menajamen semua haltersebut.

Sumbangan pendidikan terhadap pembangunan bangsa tentu bukan hanya sekedar penyelenggaraan pendidikan, tetapi pendidikan yang bermutu, baik di sisi input, process, output, maupun outcome. Input pendidikan yang bermutu adalah guru-guru yang bermutu, peserta didik yang bermutu, kurikulum yang bermutu, fasilitas yang bermutu, dan berbagai aspek penyelengaraan pendidikan yang bermutu. Proses pendidikan yang bermutu adalah proses pembelajaran yang bermutu. Output pendidikan yang bermutu adalah lulusan yang memiliki kompetesi yang disyaratkan. Sedangkan outcome pendidikan yang bermutu adalah lulusan yang mampu melanjutkan ke jenjang pendidikan yang lebih tinggi atau 
terserap pada dunia usaha atau dunia industri (Tim dosen Administrasi Pendidikan UPI, 2010).

Kepala madrasah merupakan seorang pejabat yang profesional dalam organisasi madrasah yang bertugas mengatur semua sumber daya organisasi dan bekerja sama dengan guru-guru dalam mendidik siswa untuk mencapai tujuan pendidikan serta memahami semua kebutuhan madrasah. Dengan keprofesionalan kepala madrasah, pengembangan profesionalisme guru muda dilakukan karena sesuai dengan peran dan fungsinya, salah satu cara yang dapat dilakukan oleh kepala madrasah dalam meningkatkan profesionalisme guru.

Menurut Mulyasa adalah sebagai berikut: (1) menyusun penyetaraan bagi guru yang memiliki kualifikasi SMA/D.III agar mengikuti penyetaraan S1/Akta IV, sehingga mereka dapat menambah wawasan keilmuan dan pengetahuan yang menunjang tugasnya, (2) mengikutsertakan guru-guru melalui seminar dan pelatihan yang diadakan oleh Depdiknas maupun di luar Depdiknas. Hal tersebut dilakukan untuk meningkatkan kinerja guru dalam membenahi materi dan metodologi pembelajaran, (3) revitalisasi KKG (kelompok kerja guru) dan MGMP (musyawarah guru mata pelajaran), serta (4) meningkatkan kesejahteraanguru (Mulyasa, 2007).

Keempat cara menurut mulyasa di atas belum lengkap untuk meningkatkan profesionalisme guru, cara tersebut hanya bisa berdampak pada fokus meningkatkan aspek kognitif siswa saja, tetapi aspek afektif belum menyentuh sama sekali, dalam hal ini kepala sekolah perlu punya terobosan baru dengan menerap dan menanamkan budaya religius kepada semua guru guna melengkapi dan menjadikan guru profesional yang mempunyai dampak yang baik dan unggul terhadap peserta didik yang nantinya sebagai output dari lembaga tersebut.

Budaya religius dalam suatu lembaga pendidikan sangat perlu ditekankan, sekalipun itu lembaga pendidikan berbasiskan Islam. Karena budaya religius adalah sekumpulan nilai agama yang melandasi perilaku, tradisi, kebiasaan, dan simbol-simbol yang dipraktikkan guru sebagai tenaga pendidik di madrasah. Budaya religius merupakan cara berpikir dan bertindak warga sekolah yang didasari atas nilai-nilai religius (keberagamaan) (Sahlan, 2009).

Dampak profesional guru diawali dari profesional kepala sekolah, menurut E. Mulyasa (2007) Kepala sekolah profesional dalam paradigma baru manajemen pendidikan akan memberikan dampak positif dan perubahan yang cukup mendasar dalam pembaharuan sistem pendidikan di sekolah. Dampak tersebut antara lain terhadap efektifitas pendidikan, kepemimpinan sekolah yang kuat, pengelolaan tenaga kependidikan yang efektif, budaya mutu, teamwork yang kompak, cerdas, dan dinamis, kemandirian, partisipasi warga sekolah dan masyarakat, keterbukaan (transparansi) manajemen, kemauan untuk berubah (psikologis dan fisik), evaluasi dan perbaikan berkelanjutan, responsif dan antisifatif terhadap kebutuhan. 
Madrasah Aliyah Al-Manshuriyah Sungai Baung merupakan salah satu sekolah unggulan di kabupaten Musi Rawas Utara yang berada di kecamatan Rawas Ulu. Madrasah Aliyah Al-Manshuriyah Sungai Baung terletak di jl. Ahmad Yani no.2, yang berada di dekat keramaian Kota/Kabupaten, tempatnya stategis dan mudah dijangkau oleh kendaraan umum. Masyarakat sekitar merasa bangga apabila anaknya bersekolah di Madrasah Aliyah Al-Manshuriyah Sungai Baung, karena yang diterima untuk bersekolah di Madrasah Aliyah AlManshuriyah Sungai Baung tidak sembarang peserta didik, tetapi harus peserta didik yang nilainya bagus, dan pemilihannya juga sangat selektif. Oleh karena itu, Madrasah Aliyah Al-Manshuriyah Sungai Baung sudah mendapat kepercayaan dari masyarakat sekitar bahwa sekolahan tersebut adalah sekolah unggulan dan mampu menghasilkan lulusan yang berkualitas.

Di Madrasah Aliyah Al-Manshuriyah Sungai Baung walaupun para guru pendidikan agama Islam sudah sarjana tetapi dalam menjalankan tugasnya masih membutuhkan pengarahan dan pembinaan dari kepala madrasah. Sebagai pemimpin pada lembaga pendidikan kepala madrasah di Madrasah Aliyah AlManshuriyah Sungai Baung dituntut untuk dapat meningkatkan kompetensi profesional guru pendidikan agama Islam seiring dengan perkembangan zaman. Permasalahan yang ingin diungkap oleh peneliti yaitu bagaimana manajemen kepala madrasah dalam meningkatkan kompetensi profesional guru pendidikan agama Islam sedangkan kepala madrasah Madrasah Aliyah Al-Manshuriyah Sungai Baung merupakan seorang yang sibuk sehingga waktu kepala madrasah di sekolah sangat terbatas. Bagaimana sebenarnya manajemen yang dilakukan kepala madrasah selama ini seiring dengan kemajuan ilmu pengetahuan dan teknologi, sehingga meskipun dengan waktu yang terbatas beliau selalu memantau perkembangan para guru pendidikan agama Islam dalam proses belajar mengajar.

\section{METODE PENELITIAN}

Dalam penelitian ini, penulis menggunakan jenis penelitian kualitatif dengan pendekatan deskriptif. Sumber data dalam penelitian ini adalah subyek dari mana data dapat diperolehSehingga beberapa sumber data yang dimanfaatkan dalam penelitian ini meliputi: 1) sumber data utama (primer) yaitu sumber data yang diambil penelitimelalui wawancara dan observasi, 2) sumber data tambahan (sekunder), yaitu sumber data di luar kata-kata dan tindakan yakni sumber data tertulis.

Adapun prosedur pengumpulan data, yakni metode observasi, untuk mengamati secara langsung di lapangan, terutama tentang: 1) letak geografis serta keadaan fisik Madrasah Aliyah Al-Manshuriyah Sungai Baung, 2) pengelolaan sekolah di Madrasah Aliyah Al-Manshuriyah Sungai Baung, 3) kegiatan pembelajaran di Madrasah Aliyah Al-Manshuriyah Sungai Baung, 4) keunikan yang ada di Madrasah Aliyah Al-Manshuriyah Sungai Baung. Metode Interview (Wawancara), metode ini digunakan peneliti untuk mewawancarai kepala 
madrasah dan guru pendidikan agama Islam serta waka kurikulum yang ada di MA Al-Manshuriyah untuk mengetahui hal-hal yang terjadi yang berhubungan dengan Manajemen kepala madrasah dalam meningkatkan kompetensi profesional guru pendidikan agama Islam.Metode Dokumentasi, dokumentasi yang peneliti gunakan adalah dengan mengumpulkan data yang ada di kantor Madrasah Aliyah Al-Manshuriyah Sungai Baung, tepatnya diperoleh dari bagian tata usaha (TU) dan kurikulum, baik berupa tulisan (data siswa,guru, fasilitas), gambar (struktur organisasi), profil Madrasah Aliyah Al-Manshuriyah Sungai Baung dan dokumen terkait lainnya.

Teknik analisa data; 1) reduksi data, dalam penelitian ini data yang diperoleh dari informan kunci, yaitu Kepala madrasah, Bagian Kurikulum, dan Guru Pendidikan Agama Islam, disusun secara sistematis agar memperoleh gambaran yang sesuai dengan tujuan penelitian. Begitu pula data yang diperoleh dari informan pelengkap disusun secara sistematis agar memperoleh gambaran yang sesuai dengan tujuan penelitian, 2) penyajian data, data yang sudah direduksi dan diklasifikasikan berdasarkan kelompok masalah yang diteliti, sehingga memungkinkan adanya penarikan kesimpulan atau verifikasi, 3) verifikasi, peneliti pada tahap ini mencoba menarik simpulan berdasarkan tema untuk menemukan makna dari data yang dikumpulkan.

\section{HASIL DAN PEMBAHASAN}

\section{Manajemen Kepala Madrasah dalam Meningkatkan Kompetensi Profesional Guru Pendidikan Agama Islam (PAI)}

Berdasarkan hasil wawancara yang telah peneliti lakukan di MA AlManshuriyah bahwa ada beberapa strategi kepala madrasah dalam meningkatkan komptenesi profesional guru PAI. Strategi yang dilakukan terbagi pada dua kegiatan yaitu Formal dan Informal. Sebagaimana yang diungkapkan oleh bapak Hasaksi, S.Pd selaku Kepala Madrasah. Bahwa:

"Di MA Al-Manshuriyah ini dalam meningkatkan kompetensi profesional Guru saya menggunakan dua strategi yaitu kegiatan formal dan non formal, kenapa demikian? Karena saya fikir kalau rekan-rekan guru ini terus menerus mengikuti kegiatan yang sejenis tentunya mereka akan menimbulkan rasa bosan, jenuh, dan lain sebagainya. Dan yang saya khawatirkan adala dampaknya mereka ini tidak bisa menerima ataupun menyerap apa yang telah disampaikan oleh nara sumber, misalnya dalam kegiatan seminar, penataran dll, jadi disini strategi saya selain mengikut sertakan mereka dalam kegiatan tersebut saya juga membuka kegiatan non formal diantaranya adalah saya sering mengadakan sharing dengan para guru dengan cara, kapanpun mereka bebas datang keruangan saya untuk sharing, kadangkala sebaliknya, saya juga selalu memberkan motivasi kepada Guru terutama Guru PAI yang berhubungan dengan komptenesi professional kerja mereka, selain itu juga kedisiplinan juga selalu saya contohkan, misalnya suatu hal yang kecil yaitu: 
saya selalu datang lebih awal. Dan masih banyak lagi kegiatan-kegiatan lainnya pak"

Berdasarkan hasil interview yang telah peneliti lakukan di MA AlManshuriyah Kepala Madrasah sering mengikutsertakan Guru Pendidikan Agama Islam dalam kegiatan seminar, pelatihan, diklat bahkan mengadakan study banding ke sekolah-sekolah lain dalam rangka untuk meningkatkan prestasi, dan mengembangkan wawasan tentang pendidikan islam seperti yang diungkapkan oleh Bapak Hasaksi, S.Pd Bahwa:

Strategi saya dalam menngkatkan kompetensi professional guru Pendidikan Agama Islam yaitu: saya sering mengikutsertakan Guru PAI ini untuk diklat, seminar dan juga study banding ke lembaga Islam lain yang berhubungan dengan Pengembangan Pendidikan Agama Islam khususnya. Dengan tujuan untuk terus meningkatkan mutu pendidikan Agama Islam di MA AlManshuriyah Sungai Bang ini”,

Pernyataan tersebut sama halnya dengan yang dikatakan oleh ibu Sumarni, S.Pd.I (Guru Pendidikan Agama Islam) beliau mengatakan bahwa:

Begini pak, dalam pelatihan atau seminar Kepala Madrasah selalu mengikutsertakan Guru Pendidikan Agama Islam bahkan saya sering diajak untuk study banding ke sekolah-sekolah islam lainnya, hal ini beliau lakukan demi untuk meningkatkan kompetensi profesional kami untuk meningkatkan kinerja dalam mengajar siswa dan siswi di madrasah ini"”

Di MA Al-Manshuriyah strategi yang dilakukan oleh kepala madrasah dalam meningkatkan kompetensi profesional guru PAI adalah: sering mengadakan sharing, diikutkan seminar, diklat dan pelatihan serta mengadakan study banding ke lembaga Islam lainnya.Dalam meningkatkan kompetensi profesional Guru PAI Kepala Madrasah mendorong guru untuk kreatif dan inovatif dengan melakukan beberapa pendekatan terhadap guru-guru terutama guru Pendidikan Agama Islam (PAI) yang berada di MA Al-Manshuriyah, pendekatan itu dilakukan dengan cara misalnya: Kepala Madrasah berkunjung ke ruang guru sesuai dengan apa yang disampaikan oleh Bapak Hasaksi, S.Pd selaku kepala madrasah mengatakan bahwa:

"Setiap hari saya datang ke sekolahan dari situ saya mendekati guru kemudian saya juga sering berkunjung ke ruang guru biasanya saya mengayapa mereka dengan menanyakan kabar terbaru apa yang tidak saya ketahui, terus siapa guru yang tidak masuk hari ini, selain itu juga para guru saya berikan kesempatan untuk datang ke ruang saya jika ada hal-hal yang ingin disampaikan, itu merupakan kunci keakraban saya dengan para guru pak, selain itu ketika kami bertemu, berpapasan kami selalu bertegur sapa hal ini menunjukkan hubungan yang baik antara atasan dan bawahan" 
Dari hasil interview yang peneliti lakukan menunjukkan bahwa Kepala Madrasah menjalin hubungan baik dengan para guru MA Al-Manshuriyah, Sikap Pak Hasaksi, S.Pd tersebut menjadi motivasi bagi guru-guru dan juga guru merasa diperhatikan oleh kepala madrasah sehingga jika guru merasa ada permasalahan mereka tidak segan-segan untuk membicarakan dan meminta solusi kepada kepala madrasah.MA Al-Manshuriyah selalu mengedepankan kedisiplinan baik untuk peserta didik maupun para gurunya. Kedisiplinan itu dimulai oleh Bapak Hasaksi, S.Pd yang menjabat sebagai kepala madrasah, Pak Hasaksi, S.Pd biasanya berangkat lebi awal daripada guru-guru yang lain. Seperti yang dipaparkan oleh Bapak Gunawan, S.Pd.I selaku Waka Kurikulum MA Al-Manshuriyah

"Sikap Pak Hasaksi, S.Pd sendiri yang sangat disiplin berangkat lebih awal dan pulang selalu belakangan, sehingga hal itu membuat guru-guru menjadi segan dan turut disiplin, kalau ada guru yang tidak masuk mengajar guru tersebut wajib memberitahukan kepada guru yang piket bisa lewat surat izin, via Telphon/WA beserta alas an yang tepat dan harus memberikan tugas pada siswa, jadi meski para guru tidak hadir siswa tetap bisa melakukan proses pembelajaran sebagaimana mestinya"

Karena sikap beliau tersebut guru-guru manjadi rajin dan segan jika datangnya agak terlambat, kedisiplinan tidak hanya ditujukan kepada peserta didik saja, akan tetapi guru juga perlu ditingkatkan kedisiplinannya karena guru sebagai contoh bagi para peserta didiknya. Meningkatkan kompetensi profesional guru pendidikan agama Islam (PAI) membutuhkan motivasi dan dukungan dari berbagai pihak, seperti halnya motivasi dari kepala madrasah. Seperti yang telah diungkapkan oleh ibu Sumarni, S.Pd.I selaku guru pendidikan agama Islam (PAI) Bahwa:

"Bapak Hasaksi, S.Pd selaku kepala madrasah selalu memberikan dorongan dan motivasi kepada guru pendidikan agama Islam (PAI) untuk lebih kreatif dan inovatif dalam melakukan proses pembelajaran dikelas dengan motivasi dari kepala madrasah tersebut maka, saya selaku guru pendidikan agama Islam (PAI) menjadi lebih semangat dalam menjalankan tugas saya, selain itu guru tuntut untuk membuat rencana kegiatan Mutu PAI dalam jangka waktu yang pendek, lalu kepala madrasah merealisasikannya. Hal ini juga termasuk cara memotivasi diri untuk terus meningkatkan kompetensi profesional, agar nantinya dapat menghasilkan lulusan yang berprestasi dan mempunyai daya saing yang tinggi.

Dorongan dan motivasi tidak hanya datang dari kepala madrasah akan tetapi guru pendidikan agama Islam (PAI) juga memotivasi dirinya sendiri untuk terus meningkatkan kompetensi profesionalnya. Namun dalam menjalankan strategi tersebut diatas ada beberapa hambatan yang ditemui seperti yang disampaikan 
oleh Bapak Hasaksi, S.Pd selaku kepala madrasah MA Al-Manshuriyah yang mengatakan bahwa:

"Ada beberapa hambatan yang kami hadapi dalam meningkatkan kompetensi professional guru disini, pertama kurangnya perhatian orang tua siswa pada saat dirumah, rata-rata siswa dan siswi disini orang tuanya sibuk bekerja, jadi kemungkinan besar saat siswa dan siswi ini pulang kerumah mereka masingmasing kurang mendapatkan perhatian terutama dari segi tugas sekolah, pergaulannya, yang kedua adalah sering terjadi tabrakan waktu antara waktu pelatihan dengan waktu mengajar guru, sehingga guru harus memilih antara mengajar atau ikut pelatihan, namun disini kami memberikan solusi, pertama kami mengajak wali siswa dan siswi bermusyawarah agar terlibat dalam kemajuan siswa dan siswi dengan cara mengontrol belajar siswa pada saat mereka berada dirumah serta untuk memperhatikan pergaulan mereka seharihari, yang kedua kami mengadakan kerjasama dengan lembaga-lembaga lain seperti, Sekolah lain, Dinas Kepemerintahan, dan perguruan tinggi untuk mengadakan pelatihan yang bertujuan untuk meningkatkan kompetensi profesional guru

\section{Kompetensi Profesional Guru Pendidikan Agama Islam}

Ilmu pengetahuan dan teknologi terus berkembang, jadi kompetendi professional guru PAI harus terus ditingkatkan, di MA Al-Manshuriyah kompetensi professional guru PAI cukup bagus, misalnya disamping guru PAI melaksanakan tugas pokoknya juga melaksanakan tugas tambahan seperti kegiatan keAgamaan dan juga harus membuat kelengkapan mengajar seperti: membuat RPP, Silabus, Progsem (Program Semester) dan Prota (Program Tahunan) dan ketika mengajar menggunakan metode yang sesuai dengan materi yang akan disampaikan dan agar anak itu tidak merasa jenuh maka, guru juga harus mencari metode yang kreatif dan inovatif. Guru PAI yang mengajar di MA Al-Manshuriyah juga sesuai dengan bidangnya/ahlinya.

Kompetensi guru pendidikan agama Islam (PAI) di MA Al-Manshuriyah perlu ditingkatkan, hal ini dimaksudkan untuk mengimbangi perkembangan dunia pendidikan yang semakin maju, hal ini senada dengan apa yang diungkapkan oleh Bapak Hasaksi, S.Pd selaku Kepala Madrasah di MA Al-Manshuriyah sungai baung beliau mengatakan bahwa:

"Kompetensi professional guru pendidikan agama Islam (PAI) itu perlu dan harus ditingkatkan karena untuk mengimbangi dan menyesuaikan dengan tuntutan perkembangan zaman di era globalisasi seperti sekarang kalau tidak dituntut seperti ini dikhawatirkan tantangan yang masuk baik dari dalam maupun dari luar akan mempengaruhi pola fikir dan sistem pembelajaran, nah jika hal ini tidak kita sikapi dengan baik maka kita akan ketinggalan zaman, kompetensi professional guru PAI di MA Al-Manshuriyah untuk saat ini sudah sangat bagus, misalnya disampaing guru PAI ini melaksanakan tugas pokok, 
juga melaksanakan tugas tambahan seperti kegiatan ekstrakurikuler keagamaan

Sama halnya dengan apa yang diungkapkan oleh Bapak Gunawan, S.Pd.I selaku waka kurikulum di MA Al-Manshuriyah beliau mengatakan bahwa:

"Untuk kompetensi professional guru khusunya guru PAI disini sangat baik pak, sangat baik dalam artian jurusannya pas dengan mata pelajaran yang diampuh oleh guru yang bersangkutan, kemudian kelengkapan mengajar guru (ketika mengajar dikelas selalu membuat RPP), diawal tahun ajaran selalu membuat Program Tahunan (Prota) begitupun juga disetiap semester membuat Program semester (Prosem), silabus dan ketika melaksanakan proses belajar mengajar selalu menggunakan metode yang sesuai dengan matri yang disampaikan agar anak didik tidak merasa bosan dan jenuh. Di MA AlManshuriyah ini kurikulum yang digunakan adalah kurikulum KTSP, dan setiap pendidikan harus mengikuti perkembangan zaman dan harus seiring dengan ilmu pengetahuan dan teknologi, jadi kompetensi profesional guru PAI harus terus ditingkatkan"

Sama halnya dengan yang diungkapkan oleh ibu Sumarni, S.Pd.I selaku guru pendidikan agama Islam (PAI) di MA Al-Manshuriyah Sungai baung beliau mengatakan bahwa:

"Sebelum melaksanakan kegiatan belajar mengajar saya harus mempersiapkan materi, strategi, maupun bahan ajar dengan baik. Untuk itulah setiap kali saya akan masuk kelas, saya selalu mempersiapkan atau merencanakan apa yang akan saya sampaikan nanti, bagaimana metodenya dan bagaimana evaluasi yang akan saya lakukan nantinya. Hal tersebut tentunya mengacu kepada ketentuan kurikulum yang ada, dan saya selalu menggunakan metode yang sesuai dengan materi pelajaran, dan biasanya saya juga mencari referensi dari internet pak dan juga buku pendukung. Metode itukan banyak pak, tetapi saya selalu memilih metode yang sesuai dengan materi agar siswa tidak merasa jenuh dan bosan, selain itu saya juga menggunakan metode permainan, jika waktu cuma sedikit sedangkan materi banyak saya menggunakan metode simulasi, dan terkadang saya mengajak siswa untuk belajar diluar kelas, bahkan saya jarang sekali menggunakan metode ceramah, karena saya merasa siswa itu malah tidak memperhatikan, tetapi metode atau media itupun juga tergantung dengan materi yang akan saya sampaikan"

MA Al-Manshuriyah sungai baung dari segi kualifikasi pendidikannya sudah bisa dikatakan profesional. Hal ini terbukti dengan pendidikan yang telah ditempuh oleh guru PAI disini sudah S1. Guru PAI yang mengajar disini sudah menerapkan metode pembelajaran sesuai dengan kurikulum yang berlaku dan juga 
menggunakan berbagai variasi metode pembelajaran dengan tujuan agar peserta didik tidak jenuh terhadap pembelajaran yang sedang dilaksanakan, dan guru PAI selalu membuat RPP sebelum mulai mengajar dikelas, demi kelancaran proses belajar mengajar

Kepala madrasah merupakan salah satu komponen pendidikan yang sangat berperan dalam meningkatkan kualitas pendidikan, sebagaimana diungkapkan dalam pasal 12 ayat 1 PP 28 Tahun 1990 bahwa: "kepala madrasah/madrasah bertanggung jawab atas penyelenggaraan kegiatan pendidikan, Administrasi sekolah, Pembinaan tenaga pendidikan lainnya, dan pendayagunaan serta pemeliharaan sarana dan prasarana" (Mulyasa, 2007).

Kepala madrasah dalam meningkatkan kompetensi professional guru pendidikan agama Islam (PAI) harus mempunyai strategi agar tugas kepemimpinannya berjalan dengan baik dan lancer. Pak Hasaksi, S.Pd sebagai kepala madrasah berusaha semaksimal mungkin mengupayakan bagaimana agar guru pendidikan agama Islam yang ada di MA Al-Manshuriyah bisa meningkatka kompetensi profesionalnya, strategi yang dilakukan diantaranya adalah:

Diikutkan diklat, seminar dan pelatihan. Mengikutsertakan guru dalam kegiatan pendidika dan pelatihan tenaga guru (PPTG) dan tenaga kependidikan pada umunya, hal ini bertujuan agar guru mampu merespon perubahan dan tuntutan perkembangan ilmu teknologi dan kemajuan kemasyarakatan, termasuk perubahan sistem pendidikan dan pembelajaran secara mikro (Sudarwan, 2010). Di MA Al-Manshuriyah sungai baung sering mengikut sertakan guru pendidikan agama Islam dalam Pelatihan, MGMP, KKG, seminar diklat dalam rangka untuk meningkatkan keprofesionalan, prestasi dan wawasan tentang pendidikan agama Islam, pelaksanaan penataran dan lokakarya untuk mengembangkan kemampuan guru dalam melaksanakan proses belajar mengajar. Pelaksanaannya dilakukan dengan cara mengundang seseorang atau beberapa orang ahli sebagai narasumber.

Kedisiplinan. MA Al-Manshuriyahselalu mengedepankan kedisiplinan baik itu untuk siswa dan siswi maupun gurunya. Kedisiplinan itu dimulai oleh bapak Hasaksi, S.Pd selaku kepala madrasah, dari hasil pengamatan peneliti pak Hasaksi, S.Pd biasanya berangkat lebih awal dari guru yang lain, pak Hasaksi mengambil kebijakan bahwa guru setidaknya datang kira-kira 15 menit sebelum jam pelajaran dimulai.Karena sikap pak Hasaksi, S.Pd seperti itu, sehingga guruguru rajin dan segan jika datangnya terlambat, kalau ada guru yang tidak masuk mengajar guru tersebut wajib memberitahukan kepada guru piket, baik itu melalui surat izin, via telphon/WA beserta alasannya.

Memotivasi Guru. Sebagai pemimpin yang bertanggung jawab terhadap pencapaian tujuan dengan melalui orang lain, dan diharapkan mempunyai kemampuan untuk memotivasi para guru dengan memahami apa yang menjadi kebutuhan mereka dan berusaha untuk menyiapkan alat-alat pemenuhan kebutuhan para guru, maka seorang pemimpin akan dapat mendorong para gurunya untuk bekerja lebih giat lagi.Sebagai motivator pak Hasaksi, S.Pd selaku 
kepala madrasah memiliki strategi yang tepat untuk memberikan motivasi kepada para tenaga pendidik dalam melakukan berbagai tugas dan fungsinya. Motivasi itu dapat ditumbuhkan melalui: a) penyediaan sarana dan prasarana yang memadai, sarana yang menunjang dan memadai merupakan harapan dari semua sekolah, termasuk harapan daripada kepala madrasah, makanya dia selalu berusaha untuk memperbaiki sarana yang ada agar guru merasa nyaman dalam mengajar. Prasarana atau perlengkapan juga merupakan penunjang dalam proses belajar mengajar di MA Al-Manshuriyah salah satu sarana dan prasarana yang disediakan oleh kepala madrasah adalah berupa : Jaringan Internet (Wifi), LCD dan lain sebagainya, b) disiplin, profesionalisme tenaga pendidik perlu ditingkatkan, maka dari itu pak Hasaksi, S.Pd berusaha menanamkan disiplin kepada semua bawahannya. Melalui kedisiplinan ini diharapkan dapat mencapai tujuan secara efektif dan efisien, serta dapat menghasilkan lulusan yang berkualitas. Sebagaimana peraturan tentang disiplin ini sudah dicantumkan oleh pemerintah didalam undang-undang no 53 tahun 2010 terdapat pada Bab I Pasal I dan Bab II nomor 3, 4 dan 5 yaitu: "Disiplin Pegawai Negeri Sipil adalah kesanggupan Pegawai Negeri Sipil untuk menaati kewajiban dan menghindari larangan yang ditentukan dalam peraturan perundang-undangan dan/atau peraturan kedinasan yang apabila tidak ditaati atau dilanggar dijatuhi hukuman disiplin. setia dan taat sepenuhnya kepada Pancasila, Undang-Undang Dasar Negara Republik Indonesia Tahun 1945, Negara Kesatuan Republik Indonesia, dan Pemerintah. menaati segala ketentuan peraturan perundang-undangan. melaksanakan tugas kedinasan yang dipercayakan kepada PNS dengan penuh pengabdian, kesadaran, dan tanggung jawab"

Karena menurut beliau suatu lembaga yang baik tanpa diiringi dengan disiplin yang baik maka, semuanya tidak akan bisa berjalan, karena sebuah aturan pasti memerlukan sebuah kedisiplinan yang baik oleh karena itu kepala madrasah sangat menekankan dan mengutamakan kedisiplinan dalam lembaga yang beliau pimpin dan itu semua diawali dari dirinya sendiri.

Supervisi adalah suatu aktivitas pembinaan yang direncanakan untuk membantu para guru dalam melakukan pekerjaan mereka secara efektif. Supervise sebagai salah satu fungsi pokok dalam administrasi pendidikan, bukan hanya sekedar merupakan tugas pekerjaan para pengawas, tetapi juga kepala madrasah terhadapa guru yang ada disekolahnya.Supervisi dilakukan dengan tujuan memberikan layanan dan bantuan untuk meningkatkan kualitas mengajar guru dikelas yang pada akhirnya nanti untuk meningkatkan kualitas belajar siswa, bukan saja memperbaiki kemampuan mengajar tetapi juga untuk mengembangkan potensi kualitas guru (Luk, 2008). Sehubungan dengan hal tersebut, maka kepala madrasah sebagai supervisor hendaknya pandai meneliti, mencari dan menentukan syarat-syarat mana yang diperlukan bagi kemajuan sekolahnya sehingga tujuan pendidikan disekolah dapat tercapai dengan maksimal. 
Beberapa langkah yang perlu dikerjakan supervisor antara lain yaitu: 1) membimbing guru agar dapat memiliki metode mengajar yang tepat, 2) membimbing dan mengarahkan guru dalam pemilihan bahan pelajaran yang sesuai dengan perkembangan siswa dan tuntutan dalam kehidupan masyarakat, 3) mengadakan kunjungan kelas yang teratur, untuk melakukan observasi pada saat guru mengajar dan selanjutnya didiskusikan dengan guru, 4) pada awal tahun ajaran baru, mengarahkan penyusunan silabus sesuai dengan kurikulum yang berlaku, 5) melaksanakan rapat rutin untuk membawa kurikulum pelaksanaanya di sekolah. Setiap akhir pelajaran menyelenggarakan penilaian bersama terhadap program sekolah.

Selanjutnya sebagai Implikasi tugas supervisor tersebut beberapa hal yang perlu dilakukan kepala madrasah antara lain: 1) Mengetahui keadaan/kondisi guru dalam latar belakang kehidupan lingkungan, social dan ekonominya, 2) merangsang semangat kerja guru dengan berbagai cara, 3) menguasahankan tersedianya fasilitas yang diperlukan untuk mengembangkan kemampuan guru, 4) meningkatkan partisipasi guru di lingkungan sekolah, 5) membina rasa kekeluargaan dilingkungan sekolah, 6) mempererat hubungan sekolah dengan masyarakat, komite dan wali siswa.

Kompetensi menurut Usman dalam buku Saiful Sagala yang berjudul kemampuan Profesional dan Tenaga kependidikan meliputi: 1) penguasaan terhadap landasan kependidikan, dalam kompetensi ini termasuk memahami tujuan, mengetahui fungsi sekolahdimasyarakat, 2) menguasai bahan pengajara, artinya guru harus memahami dengan baik materi pelajaran yang akan diajarkan, penguasaan terhadap materi pokok yang ada pada kurikulum maupun bahan pengayaan, 3) kemampuan menyususn program pengajaran, mencakup program menetapkan kompetensi belajar, mengembangkan bahan pelajaran dan mengembangkan strategi pembelajaran, 4) kemampuan menyususn perangkat penilaian hasil belajar dan proses pembelajaran (Sagala, 2009).

Berdasarkan hasil wawancara dan pengamatan peneliti di MA AlManshuriyah sungai baung menurut bapak Hasaksi, S.Pd selaku kepala MA AlManshuriyah sungai baung mengungkapkan bahwa : Kompetensi guru pendidikan agama Islam (PAI) sudah sangat bagus namun demikian, perlu ditingkatkan lagi karena untuk menyesuaikan dengan perkembangan ilmu pengetahuan dan teknologi serta tuntutan zaman, jadi seiring dengan itu semua maka, kompetensi profesional guru pendidikan agama Islam (PAI) di MA Al-Manshuriyah sungai baung perlu ditingkatkan lagi.

\section{SIMPULAN}

Manajemen kepala madrasah dalam meningkatkan kompetensi profesional guru pendidikan agama Islam (PAI) di MA Al-Manshuriyah sungai baung. Strategi yang dilakukan kepala madrasah dalam meningkatkan kompetensi profesional guru pendidikan agama Islam (PAI) di madrasah aliyah Al- 
Manshuriyah adalah: a) mengikutsertakan guru dalam kegiatan diklat, pelatihan dan seminar hal ini dilakukan untuk meningkatkan kompetensi professional, wawasan, prestasi tentang pendidikan agama Islam, b) mengedepankan kedisiplinan baik itu untuk peserta didik maupun guru yang ada di madrasah aliyah Al-Manshuriyah, kedisiplinan ini dimulai dari bapak kepala madrasah itu sendiri, c) memotivasi guru, motivasi dari kepala madrasah menjadikan semangat bagi para guru untuk meningkatkan kompetensi professional guru pendidikan agama Islam, serta mengadakan perbaikan, inovasi dan kreatifitas dalam mengajar, sebagai wujud nyata dalam mengembangkan kompetensi profesional guru serta menyiapkan fasilitas proses belajar mengajar, d) supervisi, pelaksanaan supervisi di MA Al-Manshuriyah sungai baung dilakukan oleh dua orang yang terdiri dari Bapak Hasaksi, S.Pd selaku kepala madrasah dan Bapak Gunawan, S.Pd.I selaku waka kurikulum, beliau berdua bersama-sama melakukan supervise tiap semester.

Penerapan dari menajemen kepala madrasah di MA Al-Manshuriyah sungai baung sudah terlaksana, kompetensi professional guru PAI di MA AlManshuriyah sudah sangat bagus, misalnya disamping guru PAI melaksanakan tugas pokoknya, juga melaksanakan tugas tambahan seperti kegiatan keagamaan dan juga selalu membuat kelengkapan mengajar seperti: membuat Rencana Pelaksanaan Pembelajaran (RPP), diawal tahun pelajaran selalu membuat program tahunan (Prota) begitupun juga tiap semester selalu membuat program semester (Prosem), silabus dan ketika dalam mengajar selalu menggunakan metode yang sesuai dengan materi yang akan disampaikan agar anak didik tidak merasa bosan dan jenuh dalam belajar.

\section{DAFTAR PUSTAKA}

Danim, S. (2010). Profesionalisasi dan Etika Profesi Guru. Bandung: Alfabeta Mulyasa, E. (2007). Menjadi Kepala Sekolah Profesional. Bandung: PT. Remaja Rosda Karya, cet ke-VII, 2007

Luk-lu, N. M. (2008). Supervisi Pendidikan, Jember: Certer For Society Studies

Sagala, S. (2009). Kemampuan Profesional Guru dan tenaga kependidikan, Bandung: Alfabeta

Sahlan, A. (2009). Mewujudkan Budaya Religius di Sekolah. Malang: UIN-Maliki press

Sulistyorini, S. (2009). Manajemen Pendidikan Islam. Yogyakarta: Teras

Tim dosen Administrasi Pendidikan UPI. (2010). Manajemen Pendidikan, Bandung: Alfabeta

Wahjosumidjo, W. (2005). Kepemimpinan Kepala Sekolah Tinjauan Teoritik dan Permasalahannya. Jakarta: Raja Grafindo Persada 